\title{
$\begin{array}{r}\text { WAGENINGEN } \\ \text { UNIVERSITY \& RESEARCH } \\ \hline\end{array}$
}

\section{Technologically achievable soil organic carbon sequestration in world croplands and grasslands}

\author{
Batjes, N. H.
}

This is a "Post-Print" accepted manuscript, which has been Published in "Land Degradation and Development"

This version is distributed under a non-commercial no derivatives Creative Commons (c) (1) $@ \Theta$ (CC-BY-NC-ND) user license, which permits use, distribution, and reproduction in any medium, provided the original work is properly cited and not used for commercial purposes. Further, the restriction applies that if you remix, transform, or build upon the material, you may not distribute the modified material.

Please cite this publication as follows:

Batjes, N. H. (2019). Technologically achievable soil organic carbon sequestration in world croplands and grasslands. Land Degradation and Development, 30(1), 25-32. https://doi.org/10.1002/ldr.3209

You can download the published version at:

https://doi.org/10.1002/ldr.3209 


\section{TECHNOLOGICALLY ACHIEVABLE SOIL ORGANIC CARBON SEQUESTRATION IN WORLD}

\section{CROPLANDS AND GRASSLANDS}

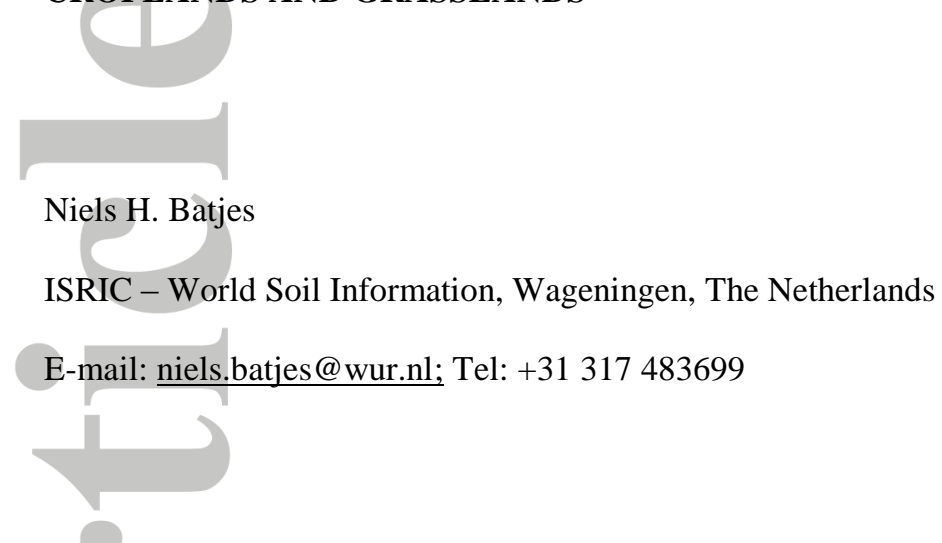

\section{Abstract}

Reported potentials for sequestration of carbon in soils of agricultural lands are overly optimistic because they assume that all degraded cropland and grassland can be subjected to best management practices. Two approaches for estimating this potential are presented. Method 1 (M1) considers literature-derived best estimates for annual SOC gains ( $\left.\mathrm{Mg} \mathrm{C} \mathrm{ha}^{-1}\right)$ by bioclimatic zone; method 2 (M2) assumes an annual C increase of 3 to 5 pro mille with respect to present SOC mass (similar to the French '4-pour-mille' initiative). Four management scenarios are considered, capturing the varying level of plausibility of meeting the full technological potential. According to M1, achievable gains range from 0.05-0.12 Pg C

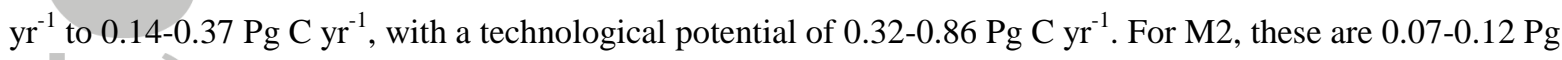
$\mathrm{C} \mathrm{yr}^{-1}, 0.21-0.35 \mathrm{Pg} \mathrm{C} \mathrm{yr}^{-1}$ and 0.60-1.01 $\mathrm{Pg} \mathrm{C} \mathrm{yr}^{-1}$. Consideration of the technological potential only and use of a proportional annual increase in SOC (M2), rather than using best estimates for soil carbon gains by bioclimatic zone (M1), will provide too 'bright a picture' in the context of rehabilitating degraded lands and mitigating/adapting to climate change. Further, M2 assumes that possible C gains will be greatest where present SOC stocks are highest, which is counter-intuitive. Although all measures aimed at increasing SOC content should be encouraged due to the creation of win-win situations, it is important to create a realistic picture of the amount of SOC gains that are feasible, based on bioclimatic and management implementation constraints.

KEYWORDS: degraded land, soil carbon sequestration, best management practices, cropland, grassland, empirical model

This article has been accepted for publication and undergone full peer review but has not been through the copyediting, typesetting, pagination and proofreading process which may lead to differences between this version and the Version of Record. Please cite this article as doi: 10.1002/ldr.3209 


\section{INTRODUCTION}

Since the 1850s, some 60 to $150 \mathrm{Pg} \mathrm{C}$ held in soil organic matter (SOM) have been lost due to land useconversion, agriculture, and disturbance (Canadell et al., 2007; R. Lal, 2010; Sanderman, Hengl, \& Fiske, 2017).

Within the next two decades, the global demand for food is projected to increase by $50 \%$, demand for water by 35-60\%, and demand for energy by 45\% (UNEP 2012). This is putting increasing pressure on many agroecosystems with adverse environmental effects (FAO \& ITPS, 2015; Springmann et al., 2018; UNCCD, 2017).

Healthy soils are critical for the functioning of terrestrial ecosystems and provisioning of ecosystem services; they can provide multiple economic, societal and environmental benefits (Banwart, Noelmeyer, \& Milne, 2015; FAO \& ITPS, 2015; UNEP, 2012). Upon their degradation, soils gradually lose their capacity to support ecosystem functions, many of which are related to the beneficial effects of soil organic carbon (SOC, or carbon

(C) held in SOM). However, depleted SOM stocks can be restored to some degree through judicious, sustainable land management (R. Lal, 2010). Such practices can also include emission reductions, for example when switching from chemical N to manure N (Wang, Pendall, Fang, Li, \& Nie, 2018).

Agriculture is a major source of greenhouse gases (GHG) and contributor to global climate change (Le Quéré et al., 2016). GHG emissions from agriculture come from deforestation, land degradation, use of fossil fuel-powered machinery, the manufacturing and distribution of chemical fertilizers, and methane emissions from livestock and irrigated rice land. On the other hand, when land is properly managed it can also be an important sink of atmospheric $\mathrm{CO}_{2}$ (Conant, Cerri, Osborne, \& Paustian, 2017; Z. Luo, Feng, Luo, Baldock, \& Wang, 2017; P. Smith et al., 2016). Plant material that is left to accumulate and decompose contributes to the formation of SOM, thus storing $\mathrm{C}$ in the soil. Over long periods of time, some of this $\mathrm{C}$ will be gradually added to stable SOC pools. The maximum (saturation) $\mathrm{C}$ level for a soil at a given location is determined by environmental factors such as rainfall, temperature and solar radiation; a lack of nutrients or capacity to supply water can reduce this saturation level.

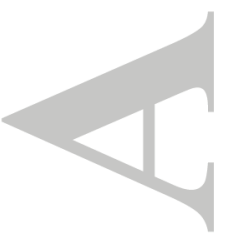


Improving SOC levels, through adoption of climate-smart agriculture (CSA), can support development and ensure food security in a changing climate. CSA is an approach aimed at a) sustainably increasing agricultural productivity and incomes, b) adapting and building resilience to climate change, and c) reducing and/or removing greenhouse gas emissions, where possible (FAO, 2015; Lipper et al., 2014; Paustian et al., 2016). Interest in this mitigation and adaptation option from the public, policy makers and international fora is of a relatively recent nature (Cowie et al., 2018; UNCCD, 2015; UNEP, 2012), particularly since the UNFCCC (UN Framework Convention on Climate Change) negotiations in Paris in December 2015. The resulting Paris Agreement aims to limit global warming to well below $2{ }^{\circ} \mathrm{C}$, ideally below $1.5^{\circ} \mathrm{C}$. To achieve this ambitious goal, reductions in emissions need to be accompanied by adaptation/mitigation activities (Banwart et al., 2015; Lorenz \& Lal, 2016; Eleanor Milne et al., 2016). Under the Paris Agreement, reductions in land-based emissions can be included in a countries' Nationally Determined Contribution. The French hosts helped jump-start the conversation in 2015 by launching the '4-pour-mille' initiative (Soussana, Saint-Macary, \& Chotte, 2015), which proposes that increasing soil $\mathrm{C}$ content by 0.4 percent per year on agricultural lands worldwide would make a significant contribution to food security and mitigating global climate change. According to Lal (2015), such an annual increase in SOC content in the upper $30 \mathrm{~cm}$ could potentially offset some $25 \%$ of anthropogenic 2014 GHG emissions annually. However, as indicated by Funk et al. (2015), in practice the achievable C gains could be much lower and innovative approaches will be needed to realise a $0.4 \%$ annual increase in soil C mass. In the absence of economic incentives and policy interventions, for example, individual farmers in tropical countries are likely to maintain their soil carbon below saturation levels (Izac, 1997). Carbon benefits on the national scale concern primarily improved food security and agricultural sustainability, while at the global level anticipated benefits from improved soil carbon management are mainly enhanced biodiversity, increased C offsets, and climate change mitigation (Banwart et al., 2015).

Overall, croplands and grasslands are considered to have the greatest potential for improving SOC stocks, in particular in those areas where soils have been historically degraded and SOC stocks are below their natural levels. Alternatively, for stable or undisturbed lands management efforts should be focused on at least preserving present SOC stocks (FAO \& ITPS, 2015; Lorenz \& Lal, 2016; UNCCD, 2015).

Best management practices (BMPs) have been recommended and these approaches have been reviewed in detail elsewhere (Banwart et al., 2015; Batjes, 1988; IPCC, 1996; Paustian et al., 2016). For example, relevant BMPs on cropland include: no-till farming, cover cropping, integrated nutrient management, complex rotations, 
and no residue burning. For grasslands, such practices include: controlled grazing, adjusted stocking rates, improved pasture with leguminous crops, and fire management. Recommended BMPs are generally region specific (FAO, 2011; Neely \& De Leeuw, 2011; WOCAT, 2007).

The objective of this study is to discuss the biophysical potential versus technologically achievable limits for increased C sequestration in the world's 'degraded' croplands and grasslands, using two different empirical approaches. In the first approach, hereafter referred to as method 1 (M1), possible annual gains in SOC in the topsoil (defined here as 0-30 cm in accordance with IPCC 2006 guidelines), considered most affected by land management practices, are calculated using literature-derived data for $\mathrm{C}$ sequestration rates $\left(\mathrm{Mg} \mathrm{C} \mathrm{ha}^{-1} \mathrm{yr}^{-1}\right)$ for defined agro-climatic regions and land use types (see references below). Alternatively, the second approach (abbreviated here as M2) uses assumptions similar to those adopted for the '4-pour-mille initiative' (Soussana et al., 2015); possible increases in SOC mass are calculated with respect to 'best estimates' for present SOC reserves $(0-30 \mathrm{~cm})$ at a given location. Further, for M1 and M2 plausible limits (scenarios) are introduced for the extent of land where the recommended practices may be applied (e.g. 10\% or 30\%), giving figures for achievable versus potential technological $\mathrm{C}$ gains.

2.
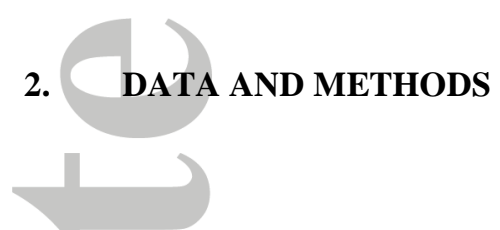

\subsection{Data}

This study used global GIS databases on climate (temperature and rainfall), land cover (as a proxy for land use), land area adversely affected by human activities (i.e. degraded), as well as soil conditions and SOC content.

Climate and land cover: Various global GIS layers for land cover and climate were considered for this exploratory study. Following on a preliminary assessment, the Global Ecological Land Units (ELU) map (Sayre et al., 2014) was selected for this purpose. ELU's represent the primary components of ecosystem structure: bioclimate, landform, lithology and land cover. Bioclimates, as defined for ELU by Sayre et al. (2014), were modified from the Global Environmental Stratification (GEnS) database (Metzger et al., 2013) and land cover was aggregated from GlobCover 2009 (Arino et al., 2012). The Global Ecological Land Units map is at a base resolution of $250 \mathrm{~m}$ and comprises 3,923 unique ELU's. 


\section{(1)}

Soil degradation status: Estimates of the scale and severity of land degradation vary significantly (FAO \& ITPS, 2015; UNCCD, 2017). For the present exploratory study, pragmatically, the Global Assessment of Humaninduced Land Degradation (GLASOD, Oldeman, Hakkeling, \& Sombroek, 1991) was used. In GLASOD, soil degradation classes are expressed in terms of declining agricultural productivity, biotic functions and restoration costs.

The definition of status of soil degradation in GLASOD includes a measure for the severity of the process and relative proportion of the delineated unit that is degraded. No information is provided on the specific location where a certain degradation type may occur in a given map unit (see Oldeman et al., 1991). As such, the map units themselves correspond with nominally degraded areas.

Soil conditions: Soil texture, nutrient content, soil moisture holding capacity and rootable depth of soil are important determinants of SOC sequestration potential within a given bioclimatic zone (Batjes, 2011; Jobbagy \& Jackson, 2000). Best estimates for 'present' soil conditions were taken from the WISE30sec database (Batjes, 2016), which provides an interim update to the Harmonised World Soil Database (FAO, IIASA, ISRIC, ISSCAS, \& JRC, 2012). The WISE30sec study provides estimates of SOC content ( $\mathrm{kg} \mathrm{C} \mathrm{m}^{-2}$ to $200 \mathrm{~cm}$ depth, considering 7 depth ranges) for each $1 \mathrm{~km}$ grid cell of the world; data for the top $30 \mathrm{~cm}$ were used for the present assessment, providing a measure for regional averages and their spatial distribution as needed for M2 type analyses.

\subsection{GIS overlays}

By their nature, ELUs provide a spatial accounting framework for assessments of ecosystem services, such as carbon storage and soil formation. GIS overlays of ELU, WISE30sec and GLASOD grid cells, resampled to 1 $\mathrm{km}$ resolution, provided the spatial basis and class-attribute data for the subsequent scenario analyses. As indicated, these only consider the land area (grid cells) under cropland and grassland, as represented here by the 'Mostly croplands' and 'Grassland, Shrub and Scrub' categories of ELU that coincide with grid cells mapped as 
degraded by human activity on the GLASOD map. Worldwide, these cover some 15.7 million $\mathrm{km}^{2}$ for croplands and 25.6 million $\mathrm{km}^{2}$ for grasslands.

\subsection{Assumptions and scenarios}

At the broad scale of the present assessment, the biophysical scope for SOC sequestration is determined mainly by climate (rainfall and temperature), followed by soil conditions such as soil texture, soil mineralogy and soil drainage and land use history (Batjes, 2011; IPCC, 2006; Jobbagy \& Jackson, 2000; Post, Emmanuel, Zinke, \&

Stangenberger, 1982). The broad rainfall-climate relation is schematised in Figure 1.

\section{> Insert Figure 1}

Despite the variability of measured responses to improved management, conservation practices, and climate change reported in the literature (Alexander, Paustian, Smith, \& Moran, 2015; Bruce et al., 1999; FAO, 2011; IPCC, 1996; Lorenz \& Lal, 2016; Minasny, Malone, et al., 2017), in most cases, measured C sequestration rates are less than 0.5 to $1 \mathrm{Mg} \mathrm{Cha}^{-1} \mathrm{yr}^{-1}$ when long-term observational data (> $20 \mathrm{yr}$ ) are considered. For the USA, for example, Chambers et al. (2016) reported annual rates of 0.3-0.5 Mg C ha ${ }^{-1}$ for Cropland and 0.04-0.21 Mg $\mathrm{C}$ ha ${ }^{-1}$ for Grazing land, while long-term studies covering the globe as reviewed by Minasny et al. (2017) point at an average annual rate of 0.2-0.6 $\mathrm{Mg} \mathrm{Cha}^{-1}$. Similar values, or best estimates, are used here for possible annual C gains in croplands and grasslands, by bioclimatic zone (M1, see Table 1).

\section{> Insert Table 1}

For method 2, SOC gains have been calculated using assumptions of the type embedded in the '4-pour-mille initiative'. In this approach, an annual increase of $0.4 \%$ (non-incremental) vis à vis current SOC stocks is introduced as a general figure to stimulate discussion and action geared at improved management of the world soil resources (de Vries, 2017; Rattan Lal, 2015; Minasny, Arrouays, et al., 2017; Minasny, Malone, et al., 2017; Soussana et al., 2015). Annual C gains of 3 to 5 per mille were assumed for M2 to provide a 'window-ofopportunity', as defined by Bouma (2001), for possible SOC gains rather than a single figure.

From a socio-economical and policy perspective, it is unlikely that $100 \%$ of the land area under consideration can be subjected to the recommended, region-specific, BMPs. Further, it will be less easy (and more costly as the status of soil degradation increases) to develop or rehabilitate large tracts of grasslands than 
croplands. For croplands, $20 \%$ has been suggested as appropriate for most developing countries (Sampson \& Scholes, 2000), with proportions up to 50-60\% considered possible for socio-economically more developed countries (P. Smith et al., 2008). Similar assumptions are used here; lower ranges are used for grassland where it is more onerous to apply BMPs than on cropland (E. Milne, Hoag, Bowen, \& Stephen, 2015). For degraded grasslands, the assumption is that $5 \%$ of the area can be improved for the 'lower limit' scenario versus $20 \%$ for the 'upper-limit' scenario (Table 2).

\section{$>$ Insert Table 2}

In consistence with IPCC (2006) guidelines, it is assumed that a new C equilibrium will be reached in the topsoil (defined as 0-30 cm) upon 20 years of sustained, judicious land management. This assumes a linear increase which is a known simplification, as soil $\mathrm{C}$ accrual rates decrease over time as $\mathrm{C}$ stocks approach a new equilibrium. In practice, this may be longer than 20 years in some regions and deeper soil layers may also be affected (Chen, Smith, \& Yang, 2015). Yet, the biophysically possible SOC gains are finite (in capacity and time) and reversible (non-permanence) when BMPs are not sustained. In economic terms this means that the yearly costs of sequestering carbon will persist after equilibrium, or soil-specific sink saturation, is reached.

Alternatively, economic benefits are associated with the improved soil functioning and provision of ecosystem services observed in a soil that builds up soil organic matter. Overall, climate smart land management should consider the balance between SOC stabilisation in the topsoil for productivity versus sequestration in the subsoil for climate mitigation (Janzen, 2006; Pete Smith et al., 2013; Torres-Sallan et al., 2017).

\section{3.}

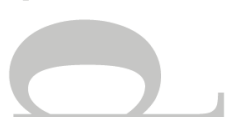

\section{RESULTS AND DISCUSSION}

\subsection{SOC mass by bioclimatic zone}

Best estimates for SOC content $\left(\mathrm{kg} \mathrm{C} \mathrm{m}^{-2}\right.$ to specified depth) by bioclimatic zone are listed in Table 3. Overall, within each temperature zone, the average SOC density increases with increasing precipitation (e.g. from Dry to Wet). For 0-30 cm, estimates range from $1.91 \mathrm{~kg} \mathrm{C} \mathrm{m}^{-2}$ for the 'hot dry' zone to $8.66 \mathrm{~kg} \mathrm{C} \mathrm{m}^{-2}$ for the 'cold wet zone'. For 0-100 $\mathrm{cm}$, the values range from $3.94 \mathrm{~kg} \mathrm{C} \mathrm{m}^{-2}$ for the 'hot dry' zone to $15.50 \mathrm{~kg} \mathrm{C} \mathrm{m}^{-2}$ for the 'cold wet' zone. This broad pattern is visualised in Figure 1, which gives a schematic representation of the scope for C 
sequestration in cropland as a function of temperature and rainfall using four broad classes. These classes are visualised in the third column of Table 1, with corresponding best estimates for $\mathrm{C}$ sequestration rates per broad rainfall-temperature zone as derived from the literature sources cited earlier.

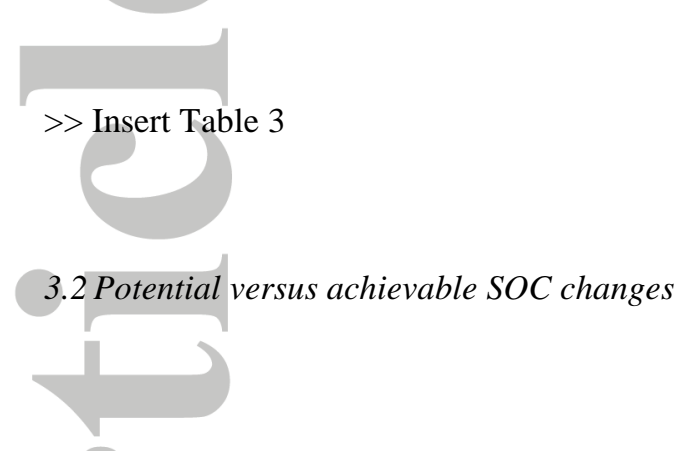

Between 0.32-0.86 $\mathrm{Pg} \mathrm{C} \mathrm{yr}^{-1}$ (M1) and 0.60-1.01 $\mathrm{Pg} \mathrm{C} \mathrm{yr}^{-1}$ (M2) can be sequestered in croplands and grasslands if $100 \%$ of the corresponding land area is subjected to best management practices. As indicated, however, this option is considered unrealistic, as it only considers the technological potential (Table 4).

\section{>> Insert Table 4}

Estimates for the potential for additional C sequestration vary widely between studies, largely due to differences in definitions (hence areal extent of given land use/cover classes), assumptions for possible annual C gains, and calculation methods (see, de Vries, 2017; Minasny, Arrouays, et al., 2017; P. Smith et al., 2016). Under the assumption that it would be possible to sequester $\mathrm{C}$ for all cropland and managed grassland at a rate

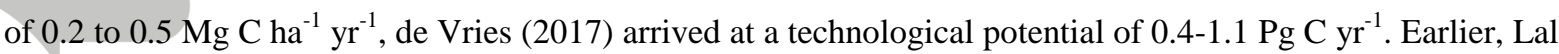

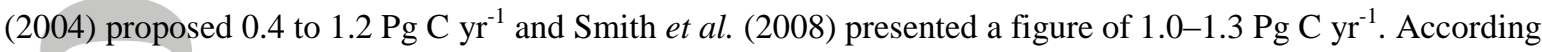
to Figure 2 in Paustian et al. (2016), the average net GHG emission reduction or removal rates are $0.3-1.6 \mathrm{Pg}$ $\mathrm{CO}_{2(\mathrm{eq})} \mathrm{yr}^{-1}$ for grazing land management and 0.3-1.5 $\mathrm{Pg} \mathrm{CO}_{2(\mathrm{eq})} \mathrm{yr}^{-1}$ for cropland management (0.08-0.44 Pg C




estimate of 0.60-1.01 $\mathrm{Pg} \mathrm{C} \mathrm{yr}^{-1}$ for M2 despite differences in datasets used. Alternatively, the bioclimatic


the socio-economic mitigation potential will be considerably lower than the technological potential (see Table 4). For example, due to lack of innovative policies and policy incentives that favour $\mathrm{C}$ sequestration or existence of behavioural or cultural barriers (Alexander et al., 2015; Funk et al., 2015; P. Smith et al., 2008). 


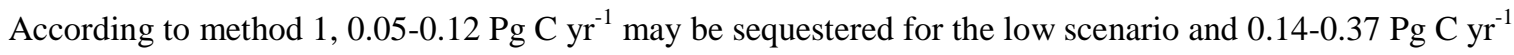

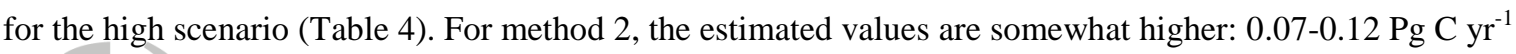
respectively $0.21-0.35 \mathrm{Pg} \mathrm{C} \mathrm{yr}^{-1}$. Likely, method 1 gives more plausible projections as it is based on measured SOC sequestration rates $\left(\mathrm{Mg} \mathrm{C} \mathrm{yr}^{-1}\right)$ per bioclimatic zone and land cover class (i.e. cropland and grassland), whereas method 2 makes inferences with respect to annual $\mathrm{C}$ increases vis à vis 'present' SOC stocks at a given location. Such stocks, however, are computed from best-available (and often only available) data for organic carbon, bulk density and proportion of coarse fragments ( $>2 \mathrm{~mm}$ ) that were sampled and analysed between 1950-2015 (Arrouays et al., 2017; Batjes, 2016; Minasny, Malone, et al., 2017; Sanderman et al., 2017). Further, an implicit assumption of method 2 is that possible $\mathrm{C}$ gains will be greatest where present SOC stocks are largest, which is counter-intuitive (see Levèvre, Fatma, Viridiana, \& Wiese, 2017; UNEP, 2012). Alternatively, method 1 draws on results of long-term field experiments carried out in defined bioclimatic and edaphic regions, which is considered more realistic for this type of exploratory studies.

At most, $10 \%$ of annual $\mathrm{CO}_{2}$ emissions (reference period 2006-2015) from fossil fuels and industry $(9.3 \pm$ 0.5 Gt C yr-1, Le Quéré et al., 2016) can be sequestered in nominally degraded croplands and grassland subject to widespread (100\%) implementation of BMPs. As illustrated in Table 4, the achievable potential will be lower than this so that one should not create unrealistic expectations as has been the case with studies that focus solely on the technological potential.

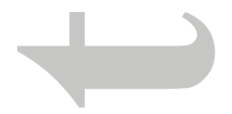

Table 4 also presents projections for possible gains in SOC stocks at the end of a 20 year implementation period, the IPCC (2006) default. It should be noted though that even a time horizon of 20 years may be too long for small scale farmers in the context of proposed carbon sequestration projects, unless short-term costs can be covered by production gains. Further, as indicated, it should be noted that in economic terms, the yearly costs of sequestering carbon will persist after equilibrium, or soil-specific sink saturation, is reached (Chung, Grove, \& Six, 2008; Stewart, Paustian, Conant, Plante, \& Six, 2009). 


\subsection{Uncertainties}

Significant uncertainty surrounds factors affecting C sequestration in soils (Baveye, Berthelin, Tessier, \& Lemaire, 2018; Harden et al., 2017); similarly, model-based approaches always encompass uncertainties (Grimm \& Behrens, 2010; Hendriks, Stoorvogel, \& Claessens, 2016; Larocque et al., 2008; Y. Luo et al., 2016; Raupach et al., 2005).

As indicated, the current empirical approach permits to discuss 'windows-of-opportunity' for achievable SOC gains. Uncertainties are mainly related to area estimates and definitions of degraded cropland and grasslands, and best-estimates of current SOC stocks and net C sequestration in a given area. Overall, information on land use change and land degradation history is seldom available, yet these are important determinants of regional SOC stock changes (Schulp \& Verburg, 2009). Further, as indicated by Sampson et al. (2000) and Smith et al. (2008), thresholds for the lower and upper limits for feasible areas that may be subjected to BMPs may need to be refined subject to region/country specific information and practicalities.

Other approaches and tools are required for reliable and verifiable estimates of changes in soil and biomass carbon at scales ranging from the individual plot to (supra) national level. Sustainable land management projects should be encouraged to use the most accurate forecasting methods possible, ranging from empirical to processbased models, given the resources available and project objectives (E. Milne et al., 2010); ideally these should be supported by field monitoring programmes for verification purposes (de Brogniez, Mayaux, \& Montanarella, 2011; van Wesemael et al., 2010). Innovative approaches based on machine learning and analyses of large historic data sets (Sanderman et al., 2017) provide new opportunities to identify regions with a high potential for SOC sequestration, based on full GHG accounting, across the full range of climate/soil/land use types of the world.

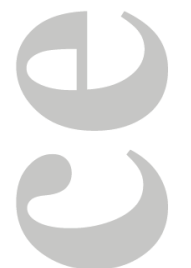

\section{CONCLUSIONS}

According to the present assumptions, at most $10 \%$ of annual $\mathrm{CO}_{2}$ emissions (average for 2006-2015) from fossil fuels and industry could be sequestered if degraded croplands and grasslands were to be subjected to widespread $(100 \%)$ implementation of BMPs. In practice, the achievable potential will be much lower than this. 
For these achievable levels to become feasible, adequate socio-economic incentives and policy interventions will be required.

It appears that approach M1 gives more plausible projections as it is based on measured SOC sequestration rates for defined bioclimatic and edaphic regions, whereas the '4-pour-mille' (M2) method makes inferences with respect to C increases vis à vis 'present' SOC stocks. Thereby, an implicit assumption of M2 is that possible $\mathrm{C}$ gains will be greatest where present SOC stocks are highest, which is counter-intuitive.

The UNCCD Land Degradation Neutrality (LDN) programme, the UN Sustainable Development Goals, as well as the French '4-pour-mille' initiative will be instrumental in realising key incentives and policy conditions. The benefits of judicious SOC management to improve long-term productivity, soil health and make better use of water resources should be stressed first, with co-benefits for climate change mitigation coming second. Besides being technologically sound, the recommended land management practices should be socially, culturally and politically acceptable, as well as economically and environmentally sound.

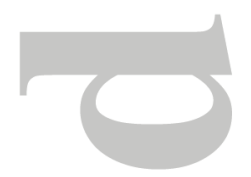

\section{ACKNOWLEDGEMENTS}

I wish to thank the anonymous reviewers for their insightful comments and suggestions, which helped to substantially improve this paper. Further, I thank my colleague Jan de Leeuw for his comments on an earlier version of the document and Eloi Ribeiro for GIS support.

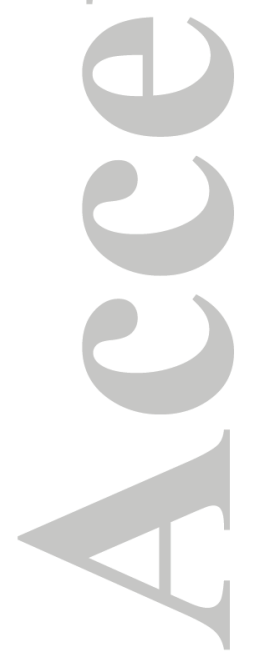




\section{REFERENCES}

Alexander, P., Paustian, K., Smith, P., \& Moran, D. (2015). The economics of soil C sequestration and agricultural emissions abatement. SOIL, 1(1), 331-339. https://doi.org/10.5194/soil-1-331-2015

Arino, O., Perez, R., Julio, J., Kalogirou, V., Bontemps, S., Defourny, P., \& Van Bogaert, E. (2012). Global Land Cover Map for 2009 (GlobCover 2009). Retrieved from: http://dx.doi.org/10.1594/PANGAEA.787668

Arrouays, D., Leenaars, J. G. B., Richer-de-Forges, A. C., Adhikari, K., Ballabio, C., Greve, M., ... Rodriguez, D. (2017). Soil legacy data rescue via GlobalSoilMap and other international and national initiatives. GeoResJ, 14, 1-19. https://doi.org/10.1016/j.grj.2017.06.001

Banwart, S. A., Noelmeyer, E., \& Milne, E. (Eds.). (2015). Soil carbon: Science, Management and policy for multiple benefits. Wallingford (UK): CABI.

Batjes, N. H. (1988). Mitigation of atmospheric $\mathrm{CO}_{2}$ concentrations by increased carbon sequestration in the soil. Biology and Fertility of Soils, 27, 230-235. https://doi.org/10.1007/s003740050425

Batjes, N. H. (2011). Soil organic carbon stocks under native vegetation - revised estimates for use with the simple assessment option of the Carbon Benefits Project system. Agriculture, Ecosystems \&

Environment, 142, 365-373. http://dx.doi.org/10.1016/j.agee.2011.06.007

Batjes, N. H. (2016). Harmonised soil property values for broad-scale modelling (WISE30sec) with estimates of global soil carbon stocks. Geoderma, 269, 61-68. http://dx.doi.org/10.1016/j.geoderma.2016.01.034

Baveye, P. C., Berthelin, J., Tessier, D., \& Lemaire, G. (2018). The “4 per 1000” initiative: A credibility issue for the soil science community? Geoderma, 309, 118-123.

https://doi.org/10.1016/j.geoderma.2017.05.005

Bouma, J. (2001). The role of soil science in the land use negotiation process. Soil Use and Management, 17, 16. https://doi.org/10.1111/j.1475-2743.2001.tb00001.x

Bruce, J. P., Frome, M., Haites, E., Janzen, H., Lal, R., \& Paustian, K. (1999). Carbon sequestration in soils. Journal of Soil and Water Conservation, 54(1), 382-389. http://www.jswconline.org/content/54/1/382.short

Canadell, J. G., Kirschbaum, M. U. F., Kurz, W. A., Sanz, M.-J., Schlamadinger, B., \& Yamagata, Y. (2007). Factoring out natural and indirect human effects on terrestrial carbon sources and sinks. Environmental 
Science \& Policy, 10(4), 370-384. https://doi.org/10.1016/j.envsci.2007.01.009

Chambers, A., Lal, R., \& Paustian, K. (2016). Soil carbon sequestration potential of US croplands and grasslands: Implementing the 4 per Thousand Initiative. Journal of Soil and Water Conservation, 71(3), 68A-74A. http://dx.doi.org/10.2489/jswc.71.3.68A

Chen, L., Smith, P., \& Yang, Y. (2015). How has soil carbon stock changed over recent decades? Global Change Biology. http://dx.doi.org/10.1111/gcb.12992

Chung, H., Grove, J. H., \& Six, J. (2008). Indications for Soil Carbon Saturation in a Temperate Agroecosystem. Soil Science Society of America Journal, 72(4), 1132-1139. http://dx.doi.org/10.2136/sssaj2007.0265

Conant, R. T., Cerri, C. E. P., Osborne, B. B., \& Paustian, K. (2017). Grassland management impacts on soil carbon stocks: a new synthesis. Ecological Applications, 27(2), 662-668. http://dx.doi.org/10.1002/eap.1473

Cowie, A. L., Orr, B. J., Castillo Sanchez, V. M., Chasek, P., Crossman, N. D., Erlewein, A., .. W Welton, S. (2018). Land in balance: The scientific conceptual framework for Land Degradation Neutrality. Environmental Science \& Policy, 79, 25-35. https://doi.org/10.1016/j.envsci.2017.10.011 de Brogniez, D., Mayaux, P., \& Montanarella, L. (2011). Monitoring, Reporting and Verification systems for Carbon in Soils and Vegetation in African, Caribbean and Pacific countries. Retrieved from: http://eusoils.jrc.ec.europa.eu/ESDB_Archive/eusoils_docs/other/EUR24932.pdf

de Vries, W. (2017). Soil carbon 4 per mille: a good initiative but let's manage not only the soil but also the expectations: Comment on Minasny et al. (2017) Geoderma 292: 59-86. Geoderma. https://doi.org/10.1016/j.geoderma.2017.05.023

FAO. (2011). The state of the world's land and water resources for food and agriculture - Managing systems at risk. Retrieved from: http://www.fao.org/docrep/015/i1688e/i1688e00.pdf

FAO. (2015). FAO success stories on climate smart agriculture. Retrieved from: http://www.fao.org/3/a$\underline{\text { i3817e.pdf }}$

FAO, IIASA, ISRIC, ISSCAS, \& JRC. (2012). Harmonized World Soil Database (version 1.2). Retrieved from: http://webarchive.iiasa.ac.at/Research/LUC/External-World-soil-database/HWSD_Documentation.pdf FAO, \& ITPS. (2015). Status of the world's soil resources (SWSR) - Main report. Retrieved from: http://www.fao.org/3/a-i5199e.pdf

Funk, R., Pascual, U., Joosten, H., Duffy, C., Genxing Pan, la Scala, N., . . Noellmenyer, E. (2015). From 
potential to implementation: An innovation framework to realize the benefits of soil carbon. In S. A. Banwart, E. Noelmeyer, \& Milne E (Eds.), Soil carbon: Science, Management and policy for multiple benefits (pp. 47-59). Wallingford (UK): CABI.

Grimm, R., \& Behrens, T. (2010). Uncertainty analysis of sample locations within digital soil mapping approaches. Geoderma, 155(3-4), 154-163. https://doi.org/10.1016/j.geoderma.2009.05.006

Harden, J. W., Hugelius, G., Ahlström, A., Blankinship, J. C., Bond-Lamberty, B., Lawrence, C. R., . . Nave, L. E. (2017). Networking our science to characterize the state, vulnerabilities, and management opportunities of soil organic matter. Global Change Biology, 24(2), e705-e718. https://doi.org/10.1111/gcb.13896

Hendriks, C. M. J., Stoorvogel, J. J., \& Claessens, L. (2016). Exploring the challenges with soil data in regional land use analysis. Agricultural Systems, 144, 9-21. http://dx.doi.org/10.1016/j.agsy.2016.01.007

IPCC. (1996). Revised 1996 IPCC Guidelines for National Greenhouse Gas Inventories. Retrieved from: https://www.ipcc-nggip.iges.or.jp/public/gl/invs1.html

IPCC. (2006). IPCC Guidelines for National Greenhouse Gas Inventories Volume 4: Agriculture, Forestry and other Land Use. Retrieved from: http://www.ipcc-nggip.iges.or.jp/public/2006gl/vol4.htm

Izac, A. M. N. (1997). Developing policies for soil carbon management in tropical regions. Geoderma, 79(1-4), 261-276. https://doi.org/10.1016/S0016-7061(97)00044-X

Janzen, H. H. (2006). The soil carbon dilemma: Shall we hoard it or use it? Soil Biology and Biochemistry, 38(3), 419-424. https://doi.org/10.1016/j.soilbio.2005.10.008

Jobbagy, E., \& Jackson, R. (2000). The vertical distribution of soil organic carbon and its relation to climate and vegetation. Ecological Applications, 10(2), 423 - 436. https://doi.org/10.1890/1051$\underline{\text { 0761(2000)010[0423:TVDOSO]2.0.CO;2 }}$

Lal, R. (2004). Soil carbon sequestration impacts on global change and food security. Science, 304, 1623 - 1627. $\underline{\text { http://dx.doi.org/10.1126/science.1097396 }}$

Lal, R. (2010). Managing soils and ecosystems for mitigating anthropogenic carbon emissions and advancing global Food Security. BioScience, 60(9), 708-721. http://dx.doi.org/10.1525/bio.2010.60.9.8

Lal, R. (2015). Cover cropping and the "4 per Thousand" proposal. Journal of Soil and Water Conservation, 70(6), 141A. http://dx.doi.org/10.2489/jswc.70.6.141A

Larocque, G. R., Bhatti, J. S., Gordon, A. M., Luckai, N., Wattenbach, M., Liu, J., . . Chen, S. H. (2008). Uncertainty and sensitivity issues in process-based models of carbon and nitrogen cycles in terrestrial 
ecosystems. In A. J. Jakeman, A. A. Voinov, A. E. Rizzoli, \& S. H. Chen (Eds.), Environmental Modelling, Software and Decision Support (Vol. 3, pp. 307-327). Amsterdam: Elsevier.

Le Quéré, C., Andrew, R. M., Canadell, J. G., Sitch, S., Korsbakken, J. I., Peters, G. P., . . Zaehle, S. (2016). Global Carbon Budget 2016. Earth Syst. Sci. Data, 8(2), 605-649. https://doi.org/10.5194/essd-8-605$\underline{2016}$

Levèvre, C., Fatma, R., Viridiana, A., \& Wiese, L. (2017). Soil organic carbon the hidden potential. Retrieved from: http://www.fao.org/3/a-i6937e.pdf

Lipper, L., Thornton, P., Campbell, B. M., Baedeker, T., Braimoh, A., Bwalya, M., .. . Torquebiau, E. F. (2014). Climate-smart agriculture for food security. Nature Climate Change, 4, 1068. http://dx.doi.org/10.1038/nclimate2437

Lorenz, K., \& Lal, R. (2016). Soil Organic Carbon-An Appropriate Indicator to Monitor Trends of Land and Soil Degradation within the SDG Framework? (No. 002413/ENG ). Retrieved from: https://www.umweltbundesamt.de/sites/default/files/medien/1968/publikationen/2016-1130_soil_organic carbon_as indicator_final.pdf

Luo, Y., Ahlström, A., Allison, S. D., Batjes, N. H., Brovkin, V., Carvalhais, N., . . Zhu, T. (2016). Towards more realistic projections of soil carbon dynamics by Earth System Models. Global Biogeochem. Cycles, 30, 40-56. http://dx.doi.org/10.1002/2015GB005239

Luo, Z., Feng, W., Luo, Y., Baldock, J., \& Wang, E. (2017). Soil organic carbon dynamics jointly controlled by climate, carbon inputs, soil properties and soil carbon fractions. Global Change Biology, 23(10), 44304439. https://doi.org/10.1111/gcb.13767

Metzger, M. J., Bunce, R. G. H., Jongman, R. H. G., Sayre, R., Trabucco, A., \& Zomer, R. (2013). A highresolution bioclimate map of the world: a unifying framework for global biodiversity research and monitoring. Global Ecology and Biogeography, 22(5), 630-638. http://dx.doi.org/10.1111/geb.12022

Milne, E., Apotsos, A., Aynekulu, E., Bationo, A., Batjes, N. H., Boone, R., . . Williams, S. (2016). Grazing lands in sub-saharan Africa and their potential role in climate change mitigation: What we do and don't know. Environmental Development, 19, 70-74. http://dx.doi.org/10.1016/j.envdev.2016.06.001

Milne, E., Hoag, D., Bowen, R., \& Stephen, W. (Eds.). (2015). Grazing Lands, Livestock and Climate Resilient Mitigation in Sub-Saharan Africa: The State of the Science: USAID

Milne, E., Sessay, M., Paustian, K., Easter, M., Batjes, N. H., Cerri, C. E. P., . . Lopez, P. J. (2010). Towards a standardized system for the reporting of carbon benefits in sustainable land management projects. 
Integrated Crop Management, 11, 105-117. http://www.fao.org/docrep/013/i1880e/i1880e04.pdf

Minasny, B., Arrouays, D., McBratney, A. B., Angers, D. A., Chambers, A., Chaplot, V., . . Winowiecki, L.

(2017). Rejoinder to Comments on Minasny et al., 2017 Soil carbon 4 per mille Geoderma 292, 59-86.

Geoderma. https://doi.org/10.1016/j.geoderma.2017.05.026

Minasny, B., Malone, B. P., McBratney, A. B., Angers, D. A., Arrouays, D., Chambers, A., .. Winowiecki, L.

(2017). Soil carbon 4 per mille. Geoderma, 292, 59-86.

http://dx.doi.org/10.1016/j.geoderma.2017.01.002

Neely, C. L., \& De Leeuw, J. (2011). Home on the Range: The Contribution of Rangeland Management to Climate Change Mitigation. In E. Wollenberg, A. Nihart, M. Grieg-Gran, \& M.-L. Tapio-Bistrom (Eds.), Climate Change Mitigation and Agriculture: Routledge.

Oldeman, L. R., Hakkeling, R. T. A., \& Sombroek, W. G. (1991). World Map of the Status of Human-Induced Soil Degradation: An explanatory Note (rev. ed.). Retrieved from:

http://data.isric.org/geonetwork/srv/eng/catalog.search\#/metadata/9e84c15e-cb46-45e2-9126$\underline{1 \mathrm{ca} 38 \mathrm{bd} 5 \mathrm{~cd} 22}$

Paustian, K., Lehmann, J., Ogle, S., Reay, D., Robertson, G. P., \& Smith, P. (2016). Climate-smart soils. Nature, 532(7597), 49-57. http://dx.doi.org/10.1038/nature17174

Post, W. M., Emmanuel, W. R., Zinke, P. J., \& Stangenberger, A. G. (1982). Soil carbon pools and world life zones. Nature, 258, 156-159. http://www.nature.com/nature/journal/v298/n5870/abs/298156a0.html

Raupach, M. R., Rayner, P. J., Barrett, D. J., DeFries, R. S., Heimann, M., Ojima, D. S., . . Schmullius, C. C. (2005). Model-data synthesis in terrestrial carbon observation: methods, data requirements and data uncertainty specifications. Global Change Biology, 11(3), 378-397. https://doi.org/10.1111/j.13652486.2005.00917.x

Sampson, R. N., \& Scholes, R. J. (2000). Additional human-induced activities - Article 3.4. In R. T. Watson, I. R. Noble, B. Bolin, N. H. Ravindranath, D. J. Verardo, \& D. J. Dokken (Eds.), Land Use, Land-Use Change, and Forestry (pp. 183-281). Cambridge: Published for the Intergovernmental Panel on Climate Change by Cambridge University Press.

Sanderman, J., Hengl, T., \& Fiske, G. J. (2017). Soil carbon debt of 12,000 years of human land use. Proceedings of the National Academy of Sciences. http://dx.doi.org/10.1073/pnas.1706103114

Sayre, R., Dangermond, J., Frye, C., Vaughan, R., Aniello, P., Breyer, S., . . Maynard, S. (2014). A New Map of Global Ecological Land Units - An Ecophysiographic Stratification Approach. Retrieved from: 
http://www.aag.org/galleries/default-file/AAG_Global_Ecosyst_bklt72.pdf

Schulp, C. J. E., \& Verburg, P. H. (2009). Effect of land use history and site factors on spatial variation of soil organic carbon across a physiographic region. Agriculture, Ecosystems \& Environment, 133, 86-97. http://www.sciencedirect.com/science/article/B6T3Y-4WH0JKW2/2/c3f4f535fd6d9865acd9fb56fd27cdea

Smith, P., Haberl, H., Popp, A., Erb, K.-h., Lauk, C., Harper, R., . . Rose, S. (2013). How much land-based greenhouse gas mitigation can be achieved without compromising food security and environmental goals? Global Change Biology, 19(8), 2285-2302. http://dx.doi.org/10.1111/gcb.12160

Smith, P., House, J. I., Bustamante, M., Sobocká, J., Harper, R., Pan, G., . . Pugh, T. A. M. (2016). Global change pressures on soils from land use and management. Global Change Biology, 22(3), 1008-1028. https://doi.org/10.1111/gcb.13068

Smith, P., Martino, D., Cai, Z., Gwary, D., Janzen, H., Kumar, P., . . Smith, J. (2008). Greenhouse gas mitigation in agriculture. Philosophical Transactions of the Royal Society B: Biological Sciences, 363(1492), 789-813. http://dx.doi.org/10.1098/rstb.2007.2184

Soussana, J.-F., Saint-Macary, J.-F., \& Chotte, J.-L. (2015). Carbon sequestration in soils: the 4 per mil concept. Paper presented at the Agriculture and agricultural soils facing climate change and food security challenges: public policies and practices, UN Climate Change Conference (Paris, Sept. 16, 2015). http://www.ag4climate.org/programme/ag4climate-session-2-3-soussana.pdf

Springmann, M., Clark, M., Mason-D’Croz, D., Wiebe, K., Bodirsky, B. L., Lassaletta, L., . . Willett, W. (2018). Options for keeping the food system within environmental limits. Nature. https://doi.org/10.1038/s41586-018-0594-0

Stewart, C. E., Paustian, K., Conant, R. T., Plante, A. F., \& Six, J. (2009). Soil carbon saturation: Implications for measurable carbon pool dynamics in long-term incubations. Soil Biology and Biochemistry, 41(2), 357-366. http://dx.doi.org/10.1016/j.soilbio.2008.11.011

Torres-Sallan, G., Schulte, R. P. O., Lanigan, G. J., Byrne, K. A., Reidy, B., Simó, I., . . Creamer, R. E. (2017). Clay illuviation provides a long-term sink for C sequestration in subsoils. Scientific Reports, 7, 45635. http://dx.doi.org/10.1038/srep45635

UNCCD. (2015). Land Degradation Neutrality: Resilience at local, national and regional levels. Retrieved from: http://catalogue.unccd.int/858_V2_UNCCD_BRO_.pdf

UNCCD. (2017). The Global Land Outlook (First Edition). Retrieved from: 
http://archive.unccd.int/download/GLO_Full_Report_hi_res.pdf

UNEP. (2012). The benefits of soil carbon - managing soils for multiple, economic, societal and environmental benefits. In UNEP Yearbook - Emerging issues in our global environment 2012 (pp. 19-33). Nairobi:

United Nations Environmental Programme.

van Wesemael, B., Paustian, K., Andrén, O., Cerri, C., Dodd, M., Etchevers, J., . . Siebner, C. (2010). How can soil monitoring networks be used to improve predictions of organic carbon pool dynamics and $\mathrm{CO}_{2}$ fluxes in agricultural soils? Plant and Soil, 1-13. http://dx.doi.org/10.1007/s11104-010-0567-z

Wang, M., Pendall, E., Fang, C., Li, B., \& Nie, M. (2018). A global perspective on agroecosystem nitrogen cycles after returning crop residue. Agriculture, Ecosystems \& Environment, 266, 49-54

https://doi.org/10.1016/j.agee.2018.07.019

WOCAT. (2007). Where the land is greener: Case studies and analysis of soil and water conservation initiatives worldwide Berne: CTA, UNEP, FAO and CDE.






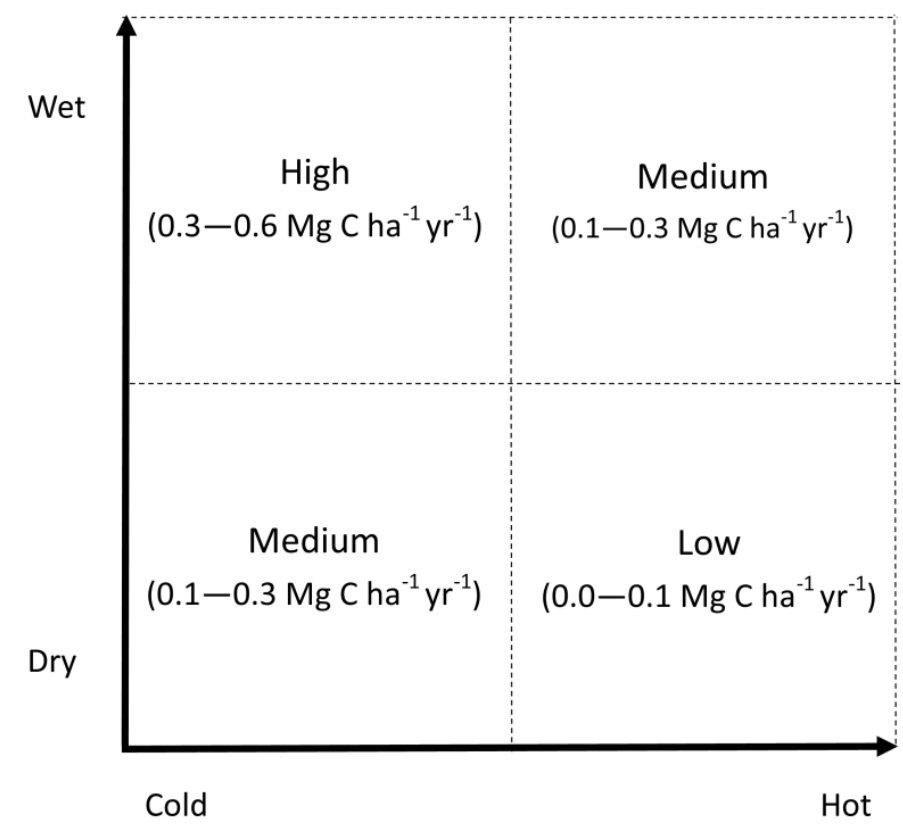

Figure 1. Schematic representation for scope for carbon sequestration in cropland as a function of temperature (x-axis) and rainfall (y-axis). Assumed ranges for annual $\mathrm{C}$ gains in croplands are shown in brackets (see text for sources consulted); see Table 2 for assumptions by bioclimatic zone for croplands and rangelands. 
Table 1. Assumptions for SOC sequestration rates per broad bioclimatic zone (method 1).

\begin{tabular}{|c|c|c|c|}
\hline Bioclimatic region & \multirow{2}{*}{$\begin{array}{c}\text { SOC } \\
\text { sequestration } \\
\text { class }^{\text {a }}\end{array}$} & \multicolumn{2}{|c|}{$\begin{array}{l}\text { SOC sequestration rate } \\
\left(\mathrm{Mg} \mathrm{C} \mathrm{ha}^{-1} \mathrm{yr}^{-1}\right)\end{array}$} \\
\hline Temperature & & Grassland & Cropland \\
\hline Cold & Medium & $0.05-0.15$ & $0.10-0.30$ \\
\hline Cool & Medium & $0.05-0.15$ & $0.10-0.30$ \\
\hline Warm & Low & $0.00-0.05$ & $0.00-0.10$ \\
\hline Hot & Low & $0.00-0.05$ & $0.00-0.10$ \\
\hline Semi-dry & Medium & $0.05-0.15$ & $0.10-0.30$ \\
\hline Cool & Medium & $0.05-0.15$ & $0.10-0.30$ \\
\hline Jarm & Low & $0.00-0.05$ & $0.00-0.10$ \\
\hline Hot & Low & $0.00-0.05$ & $0.00-0.10$ \\
\hline Cold & High & $0.15-0.30$ & $0.30-0.60$ \\
\hline Cool & High & $0.15-0.30$ & $0.30-0.60$ \\
\hline Warm & Medium & $0.05-0.15$ & $0.10-0.30$ \\
\hline Hot & Medium & $0.05-0.15$ & $0.10-0.30$ \\
\hline Cold & High & $0.15-0.3$ & $0.30-0.60$ \\
\hline Cool & High & $0.15-0.30$ & $0.30-0.60$ \\
\hline Warm & Medium & $0.05-0.15$ & $0.10-0.30$ \\
\hline Hot & Medium & $0.05-0.15$ & $0.10-0.30$ \\
\hline
\end{tabular}

${ }^{a}$ Inferred SOC sequestration classes (see Figure 1) for given bioclimatic region. The corresponding average SOC content $\left(\mathrm{kg} \mathrm{C} \mathrm{m}^{-3}\right)$ is shown in Table 3 for five depth ranges.

${ }^{\mathrm{b}}$ Representative ranges derived from the literature, see text for sources consulted.

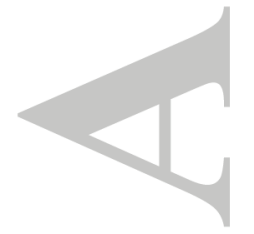


Table 2. Scenarios for proportion of degraded cropland and grassland that may be subjected to improved management practices subject to adoption of appropriate socio-economic incentives and policy measures.

\begin{tabular}{|c|c|c|c|c|}
\hline \multirow[t]{3}{*}{ Land cover class ${ }^{a}$} & \multicolumn{4}{|c|}{ Scenarios for 'reclaimable' area $(\%)^{b}$} \\
\hline & \multicolumn{3}{|c|}{ Achievable range } & \multirow[t]{2}{*}{ Potential } \\
\hline & Low & Medium & High & \\
\hline Cropland & 10 & 30 & 60 & 100 \\
\hline Grassland & 5 & 10 & 20 & 100 \\
\hline
\end{tabular}

a These classes correspond to the 'Mostly cropland' respectively 'Grassland, Shrub or Scrub' units of the Global Ecological Land Units map (Sayre et al 2014), as occurring in 'GLASOD-degraded' regions (Oldeman et al 1991), see text for details.

${ }^{\mathrm{b}}$ Four scenarios are considered for each model (M1 and M2, see text). Technological potential assumes $100 \%$ of the area under consideration can be subjected to best management practices (BMPs) aimed at sustainable land management. Achievable range refers to the proportion of degraded croplands and grasslands that may actually be reclaimed using BMPs, considering three scenarios (Low, Medium and High); indicative proportions for 'reclaimable' area are based on Sampson \& Scholes (2000) and Smith et al. (2008). Projections for both methods and four scenarios are presented in Table 4. 
Table 3. Average SOC density by bioclimatic zone

\begin{tabular}{|c|c|c|c|c|c|c|}
\hline \multirow{2}{*}{$\begin{array}{l}\text { Bioclimatic zone }^{\mathrm{a}} \\
\text { Depth }(\mathrm{cm})\end{array}$} & \multicolumn{5}{|c|}{$\begin{array}{c}\text { SOC content }^{\mathrm{b}} \\
\left.(\mathrm{kg} \mathrm{C} \mathrm{m})^{-2}\right)\end{array}$} & \multirow{2}{*}{$\begin{array}{r}\text { Extent } \\
\left(10^{6} \mathrm{~km}^{2}\right)\end{array}$} \\
\hline & $0-30$ & $0-50$ & $0-100$ & $0-150$ & $0-200$ & \\
\hline Cold Dry & 4.11 & 5.67 & 7.94 & 9.54 & 11.02 & 0.16 \\
\hline Cold Semi-Dry & 6.29 & 8.19 & 10.57 & 12.20 & 13.45 & 1.10 \\
\hline Cold Moist & 7.43 & 9.63 & 12.50 & 14.48 & 16.02 & 0.90 \\
\hline Cold Wet & 8.66 & 11.27 & 15.50 & 20.25 & 23.38 & 5.99 \\
\hline Cool Dry & 2.48 & 3.52 & 5.18 & 6.33 & 7.40 & 1.15 \\
\hline Cool Semi-Dry & 4.38 & 5.99 & 8.30 & 9.75 & 10.90 & 6.67 \\
\hline Cool Moist & 6.98 & 9.43 & 12.56 & 14.41 & 15.96 & 2.28 \\
\hline Cool Wet & 7.75 & 10.25 & 13.96 & 16.80 & 18.98 & 5.35 \\
\hline Warm Dry & 2.07 & 2.84 & 4.14 & 5.06 & 5.82 & 1.42 \\
\hline Warm Semi-Dry & 3.22 & 4.42 & 6.35 & 7.66 & 8.78 & 4.61 \\
\hline Warm Moist & 5.18 & 6.91 & 9.45 & 11.14 & 12.61 & 1.12 \\
\hline Warm Wet & 6.06 & 7.99 & 10.79 & 12.66 & 14.44 & 4.38 \\
\hline Hot Dry & 1.91 & 2.66 & 3.94 & 4.89 & 5.66 & 7.90 \\
\hline Hot Semi-Dry & 3.14 & 4.29 & 6.18 & 7.53 & 8.63 & 9.44 \\
\hline Hot Moist & 4.56 & 6.05 & 8.39 & 10.09 & 11.48 & 3.91 \\
\hline Hot Wet & 5.38 & 7.34 & 10.56 & 12.98 & 15.10 & 20.74 \\
\hline
\end{tabular}

a Bioclimatic zones as defined by Sayre et al. (2014)

b SOC content to specified depth according to WISE30sec soil database (Batjes 2016). Data for the topsoil (0$30 \mathrm{~cm}$ ) are considered in this assessment, see text.

c Extent of nominally degraded land according to GLASOD $\left(\sim 77.1 \times 10^{6} \mathrm{~km}^{2}\right)$, which only covers the $72^{\circ} \mathrm{N}$ to $57^{\circ} \mathrm{S}$ window (Oldeman et al. 1991); Arctic zone is excluded from the analyses. 
Table 4. Estimated potential and achievable SOC sequestration in the world's croplands and grasslands

\begin{tabular}{|c|c|c|c|c|c|c|c|c|c|}
\hline & \multirow[t]{3}{*}{$\begin{array}{l}\text { Land cover } \\
\text { class }\end{array}$} & \multicolumn{4}{|c|}{$\begin{array}{l}\text { Annual SOC gains } \\
\qquad\left(\mathrm{Pg} \mathrm{C} \mathrm{yr}^{-1}\right)\end{array}$} & \multicolumn{4}{|c|}{$\begin{array}{l}\text { Cumulative SOC gains } \\
\text { (Pg C over } 20 \mathrm{yr})\end{array}$} \\
\hline & & \multirow{2}{*}{$\begin{array}{l}\text { Potential } \\
\text { range }^{\mathrm{b}}\end{array}$} & \multicolumn{3}{|c|}{$\begin{array}{c}\text { Achievable range } \\
--\end{array}$} & \multirow{2}{*}{$\begin{array}{c}\text { Potential } \\
\text { range }\end{array}$} & \multicolumn{3}{|c|}{ Achievable range } \\
\hline & & & Low & Medium & High & & Low & Medium & High \\
\hline \multirow[t]{2}{*}{$\overline{\mathrm{M} 1}$} & Cropland & $0.20-0.52$ & $0.04-0.11$ & $0.08-0.21$ & $0.12-0.32$ & $4.08-10.49$ & $0.82-2.10$ & $1.63-4.20$ & $2.45-6.29$ \\
\hline & Grassland & $0.12-0.34$ & $0.01-0.02$ & $0.01-0.03$ & $0.02-0.05$ & $2.30-6.79$ & $0.12-0.34$ & $0.23-0.68$ & $0.35-1.02$ \\
\hline & $\begin{array}{l}\text { Cropland \& } \\
\text { Grassland }\end{array}$ & $0.32-0.86$ & $0.05-0.12$ & $0.09-0.24$ & $0.14-0.37$ & $6.38-17.28$ & $0.94-2.44$ & $1.86-4.87$ & $2.80-7.31$ \\
\hline \multirow[t]{3}{*}{ M2 } & Cropland & $0.26-0.44$ & $0.05-0.09$ & $0.11-0.18$ & $0.16-0.26$ & $5.27-8.79$ & $1.05-1.76$ & $2.11-3.52$ & $3.16-5.27$ \\
\hline & Grassland & $0.34-0.57$ & $0.02-0.03$ & $0.03-0.06$ & $0.05-0.09$ & $6.83-11.39$ & $0.34-0.57$ & $0.68-1.14$ & $1.03-1.71$ \\
\hline & $\begin{array}{l}\text { Cropland \& } \\
\text { Grassland }\end{array}$ & $0.60-1.01$ & $0.07-0.12$ & $0.14-0.24$ & $0.21-0.35$ & $12.10-20.18$ & $1.39-2.33$ & $2.79-4.66$ & $4.19-6.98$ \\
\hline
\end{tabular}

a Method 1 (M1) considers a lower and upper limit for annual C gains by bioclimatic region and land cover class (Table 1); computed areaweighted values for this are 0.12-0.32 $\mathrm{MgC} \mathrm{ha}^{-1} \mathrm{yr}^{-1}$ for Cropland and 0.06 to $0.15 \mathrm{Mg} \mathrm{C} \mathrm{yr}^{-1} \mathrm{ha}^{-1}$ for Grassland. The 'x-pour-mille' type method (M2) considers annual C increases of 3 to 5 pro mille with respect to present SOC mass ( $0-30 \mathrm{~cm}$ depth). See text for methodological details and GIS databases used.

${ }^{\mathrm{b}}$ Full technological potential assumes that best management practices (BMPs) are established on 100\% of degraded lands. Achievable range assumes a given (realistic) proportion of degraded lands can be reclaimed using BMPs (Low, Medium, High. See Table 2 for details).

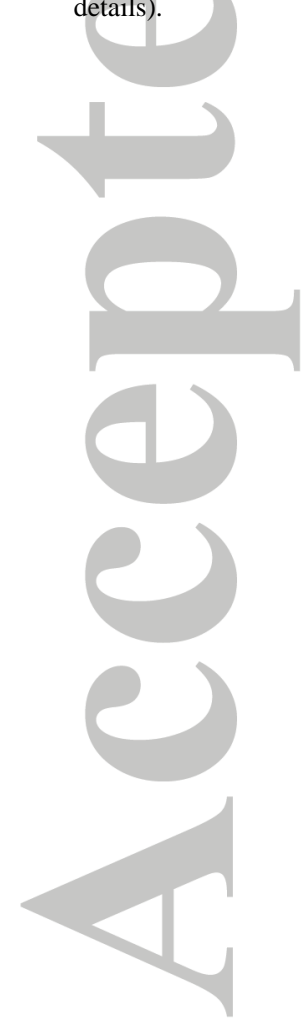

